\title{
Gatekeeper power: understanding the influence of lead firms over transnational sustainability standards
}

\author{
Hamish van der Ven (D) \\ Department of Political Science and School of Environment, McGill University, Montreal, \\ QC, Canada
}

\begin{abstract}
Do retailers and supermarkets hold power over third-party transnational sustainability standards? If so, what is the nature of their power, when and how do they use it and to what ends? Using the counterintuitive case of Walmart's efforts to improve the Best Aquaculture Practices standard for sustainable aquaculture, I develop a conceptualization of business power that flows from the position of retailers and supermarkets as lead firms within buyer-driven global value chains (GVCs). This position affords them considerable leverage over transnational sustainability standards (TSS) through their ability to act as 'gatekeepers' to their networks of suppliers, thereby controlling the degree to which sustainability standards gain market uptake. However, this power can be constrained or redirected by value chain and sector-specific conditions that may shift the balance of power towards other actors in a production network. As a result, lead firms may sometimes counterintuitively advocate for TSS that are more inclusive, independent and demanding. This article brings together the literatures on GVCs, global production networks, transnational governance and business power in global governance to offer an initial framework for theorizing power dynamics between multinational corporations and the transnational standard setters that seek to govern them.
\end{abstract}

\section{KEYWORDS}

Business power; Gatekeeper power; global value chains; global production networks; transnational sustainability standards; transnational governance

\section{Introduction}

Transnational sustainability standards (TSS) leverage the reach of global value chains $(\mathrm{GVCs})^{1}$ to steer the behavior of businesses around the world towards social and environmental goals. These standards are often, though not always, created and managed by third-party standard setters, organizations that are financially and legally independent from the firms they seek to govern. The ability of TSS to achieve their governance outcomes is contingent on the existence of GVCs, and increasingly, on the power of 'lead firms' within GVCs to demand that their suppliers get certified to a particular standard. ${ }^{2}$ Yet to date, the power of lead firms over the form and content of TSS remains under-theorized. The GVC literature remains

CONTACT Hamish van der Ven hamish.vanderven@mcgill.ca School of Environment, McGill University, Leacock Building, Room 414, 855 Sherbrooke Street West, Department of Political Science and Montreal, QC H3A 2T7, Canada. 
primarily concerned with the distribution of power within GVCs, but has thus far devoted little attention to how GVC power dynamics also shape those actors outside of the value chain (Gereffi, 2014; Gereffi, Humphrey, \& Sturgeon, 2005). The global production network (GPN) literature offers further insights into beyondGVC power relations by conceptualizing GPNs as contested organizational fields wherein power is asymmetrical and dispersed across multiple types of actors (Henderson, Dicken, Hess, Coe, \& Yeung, 2002; Levy, 2008). However, it remains vague on the conditions that tilt the balance of power towards particular actors within a GPN. Lastly, the business power in global governance literature is useful for identifying the mechanisms through which power operates (Fuchs, 2005, 2007; Fuchs \& Lederer, 2007), but underemphasizes the role of positionality within GVCs in alternately expanding or constraining the power of lead firms.

The goal of this paper is to engage these literatures and consider how power configurations within GVCs shape the form and efficacy of the transnational regulatory institutions established to govern them. It asks: do lead firms hold power over TSS? In which types of GVCs or commercial sectors will lead firms hold more or less power over TSS? Through what mechanisms does this power operate? And to what ends? I argue that lead firms project power outward by acting as 'gatekeepers' to their broader networks of suppliers, thereby affording them tremendous influence over the ostensibly independent TSS that seek to govern them. 'Gatekeeper power', as I term it, may be particularly pronounced in hierarchical, buyer-driven GVCs in commercial sectors characterized by few lead firms and multiple sustainability standards. I further argue that the consequences of lead firm gatekeeper power over TSS are both dynamic and contingent. Whereas some scholars have been quick to associate the power of lead firms with regulatory capture and downward pressure on the stringency of TSS (Bennett, 2017; Jaffee \& Howard, 2010), I suggest that stronger organizational impartiality and more stringent standards are also possible. ${ }^{3}$ Specifically, lead firms can - in cases where they face considerable scrutiny over value chain sustainability practices - actually increase the potential for desirable global governance outcomes from third-party standard setters by pressuring them to become more open, transparent and accountable.

As an inductive and exploratory effort, my primary aim is conceptual development and hypothesis building. The impetus for this article is a counterintuitive case where a particular lead firm (Walmart) exerts gatekeeper power over one of the leading TSS for aquaculture (Best Aquaculture Practices). Explaining the Walmart case requires integrating the GVC, GPN, transnational governance and business power in global governance literatures to map some of the mechanisms through which GVC power dynamics ripple outwards to affect transnational governance institutions. This sets the stage for a more fine-grained analysis of how different types of GVCs and sectoral conditions may affect emergent forms of transnational governance. The article concludes by reviewing implications for theory on GVCs, GPNs and transnational governance and consequences of gatekeeper power for achieving global governance outcomes.

\section{Entangled origins of TSS and global agrifood value chains}

Understanding the power dynamics between lead firms and TSS requires first taking a brief tour of one of the commercial sectors where these dynamics have played 
out. The past 30 years have witnessed a massive transformation in the global agrifood system. New technology combined with liberalized trade have made it easier than ever for food products to move across borders (Fold \& Pritchard, 2005). The result has been the emergence of GVCs for agrifood products like seafood, produce and commodity crops. A significant consequence of this transformation has been the concentration of capital into the hands of an ever-smaller group of 'megabuyers', principally supermarkets and retail chains and the exclusion of smaller producers from export markets (Burch \& Lawrence, 2007; Fuchs, Kalfagianni, \& Arentsen, 2009; Selwyn, 2013). The consolidation of power in the agrifood sector is the product of a number of factors. Supermarkets in the industrialized world have the option of sourcing high-volume and low-price products from a range foreign markets. A lack of asset specificity, free capital mobility and fragmented networks of global production mean that buyers can change suppliers with relative ease. This places power squarely in the hands of large end-use buyers and means that suppliers must often do whatever is necessary to maintain relationships with lead firms and their intermediaries (Reardon, Barrett, Berdegué, \& Swinnen, 2009). Thus, in the parlance of the GVC literature, many agrifood chains are 'buyerdriven' because the purchasing power of large downstream retailers and supermarkets like Walmart or Carrefour offers them power over suppliers that can be used to specify what, how, when, where and by whom goods are produced (Gereffi \& Korzeniewicz, 1994). ${ }^{4}$ The power of retailers and supermarkets is particularly pronounced when food production networks are fragmented, as they often are in fresh fruit and vegetables (Lee, Gereffi, \& Beauvais, 2012; Selwyn, 2013).

At the same time, industry consolidation has also placed novel constraints on how lead firms can exercise their power. Mega-buyers are increasingly under intense scrutiny for their procurement policies (Mayer, 2014). Their well-known brand names are vulnerable targets for value chain activism by social and environmental NGOs (Dauvergne, 2016; Dauvergne \& LeBaron, 2014; Dauvergne \& Lister, 2013; Levy, 2008). For example, brands like Cadbury, Mars and Hershey have all come under scrutiny for sourcing unsustainable cocoa and palm oil linked to deforestation in Southeast Asia (Dauvergne \& Lister, 2013). In many cases, NGO naming-and-shaming campaigns affect retailers' bottom lines. Not only do consumers tend to avoid firms and products that do not reflect their values, but investors are increasingly conscious of the risks of bad publicity to corporate value. Namingand-shaming campaigns can adversely affect both sales and share price (Bartley \& Child, 2011).

These entangled historical processes - the emergence of agrifood GVCs and growing scrutiny on the lead firms within them - help explain the emergence of third-party TSS. ${ }^{5}$ Certifications and eco-labels for agrifood mimic earlier schemes like Forest Stewardship Council (FSC) certification that sought to establish transnational standards for sustainable forestry (Cashore, Newsom, \& Auld, 2004). Third-party standard setters perform a number of useful functions for lead firms. First, they can help pre-empt more coercive forms of regulation from state regulators (Prakash, 2001). Second, they can help firms appeal to new markets of green consumers, ethical investors, or environmentally-minded employees (van der Ven, 2014). TSS offer lead firms the prospect of garnering 'club goods' or exclusive benefits that provide an advantage over competing firms (Potoski and Prakash, 2005, 2010). In competitive sectors, having a third-party environmental label or 
certification can be an important source of differentiation from competitors. Third, they offer an additional layer of impartiality and legitimacy to corporate environmentalism that can help strengthen relations with ENGOs and minimize the risk of naming-and-shaming campaigns. This independence is also what affords unelected standard setters the 'political legitimacy' necessary to govern authoritatively (Bernstein \& Cashore, 2007). For consumers and concerned stakeholders, TSS serve as marks of trust that reduce information asymmetries between producers and consumers. They provide a measure of assurance that lead firms are working with independent organizations to mitigate social and environmental impacts along their GVCs. While there is variation in the design and administration of TSS, their core features and the function they provide to lead firms is largely the same.

In most cases, independence is signaled by the presence of a freestanding decision-making body that determines the content of TSS. To be independent, its membership cannot solely represent producers (who must comply with the standard) or buyers (who sell certified products), since both might have an incentive to lower the threshold of achievement required for certification. Nor too can the standard setter be responsible for determining which producers meet its standard, since this might present a conflict of interest. Many standard setters derive revenues from certification and logo licensing; hence, there may be an incentive for standard setters to certify firms to their own standards. To preserve impartiality and independence, the task of auditing producers against a TSS is normally delegated to a financially independent conformance assessment body (CAB).

In recent years, TSS have gone mainstream as lead firms enthusiastically embrace sustainable sourcing commitments in partnership with third-party standard setters. Costco, for example, has partnered with the Marine Stewardship Council (MSC) and Aquaculture Stewardship Council (ASC) as part of its commitment to source seafood exclusively from sustainable sources (Costco, 2017). McDonalds has committed to using $100 \%$ Roundtable on Sustainable Palm Oil (RSPO) certified ingredients in its products by 2020 (McDonalds, 2017). Tata Global Beverages - the world's second-largest manufacturer and distributor of tea has publicly committed to sourcing $100 \%$ of its tea from Rainforest Alliance Certified, Trustea, or UTZ Certified farmers by 2020 (Tata, 2017). Other examples abound, but all reflect a common trend towards partnering with legally and financially independent organizations to design, implement and enforce sustainable sourcing standards.

Since independence and impartiality comprise the added value of third-party TSS over unilateral corporate environmentalism, there is good cause to inquire into the nature of power and independence between lead firms and standard setters. An exploratory case study offers a useful starting place for conceptualizing power dynamics and building hypotheses inductively. I select aquaculture as a case because it in many ways typifies trends observed in other agrifood GVCs. Much like other sectors, aquaculture can be characterized as a buyer-driven GVC where lead firms have the option of sourcing from a range of foreign markets and changing suppliers easily due to high capital mobility and low asset specificity. Production is overwhelmingly concentrated in the developing world (particularly Asia) and diffused across smaller production units (FAO, 2014). Furthermore, as in many agrifood GVCs, economic leverage is increasingly consolidated amongst a handful of mega-buyers (Engle, Quagrainie, \& Dey, 2016). Within North America, 
Walmart is a key player, comprising $14.5 \%$ of all American food and grocery sales, roughly double that of its nearest competitor (Cheddar Berk, 2017). Lastly, aquaculture is governed by a diverse set of TSS originating alternately from industry organizations, NGOs and multistakeholder processes (Darnall, Ji, \& Potoski, 2017; van der Ven, 2015). Hence, the fragmented nature of TSS for aquaculture is analogous to systems of transnational governance in many other sectors.

Outside of methodological reasons, aquaculture is empirically interesting because it has not yet received extensive scholarly treatment. Global aquaculture production is a $\$ 160$ billion USD per year industry where production volumes are increasing on every continent (FAO, 2016). The industry is tied to an array of urgent social and environmental challenges, from concerns over modern slavery to mangrove deforestation and biodiversity loss (Marschke \& Vandergeest, 2016; Merino, Barange, Mullon, \& Rodwell, 2010). By some estimates, aquaculture now comprises over $50 \%$ of the seafood consumed by humans (FAO, 2016) and production may need to double again by 2050 in order to meet the demands of a growing population (Waite, Phillips, \& Brummett, 2014). Hence, the stakes for TSS in aquaculture are particularly high.

Within aquaculture, I draw insights into the nature, mechanisms and consequences of power between lead firms and third-party TSS through a close examination of Walmart's role in reshaping the Best Aquaculture Practices (BAP) standard for sustainable aquaculture. The Walmart-BAP interaction is a counterintuitive case wherein Walmart's power and influence pushed BAP to become more rigorous and impartial in the procedures it uses to set and enforce standards. In presenting this single case, my goal is to set up an empirical puzzle that lacks an easy explanation in the extant GVC, GPN and business power in global governance literatures. To be clear, this is an exercise is inductive hypothesis building. I do not imply that the Walmart-BAP interaction is generalizable across all other agrifood sectors. Rather, a careful examination of the specific characteristics of this case and the outcome they produced provides a means of identifying the variables that may affect lead firm-TSS power dynamics in other GVCs. Throughout the following section, I draw data from both key informant interviews with 10 relevant TSS personnel as well as web-based archival research using the Wayback Machine to trace how organization-level policies evolved over time. ${ }^{6}$

\section{Curious case of Walmart and Best Aquaculture Practices}

The BAP program for sustainable aquaculture has changed significantly since its inception in 1997. Much of its evolution it can be attributed to the influence of major seafood retailers, most notably, Walmart. What was initially a small, inward-facing, industry-dominated standard gradually morphed into a large, broadly representative, multistakeholder organization. The principal motivation for this organization-level change was the interest of large seafood buyers in the BAP program.

BAP is one of the most widely-used standards for sustainable aquaculture. Certified production was over 2 million metric tons in 2017, nearly double that of the competing Aquaculture Stewardship Council (ASC) (ASC, 2017; BAP, 2017). One can find the BAP logo - three white fish in a head-to-tail circle against a blue background - on a range of farmed seafood products in supermarkets around the world, from Safeway in Canada to Sainsbury's in the UK. The BAP program was 
initially launched in response to vocal opposition to shrimp farming from ENGOs. Greenpeace in particular was concerned about the consequences of 'all-you-can-eat' offers from Red Lobster and other American chains for producers and the environment in Bangladesh, Ecuador and India (Mulvaney, 1998). The BAP program was intended to address the concerns of environmental groups by creating a unitary industry standard that would eliminate the least sustainable practices from aquaculture. Of particular concern were the deforestation of tropical mangroves and the overuse of antibiotics.

In 1999, the Global Aquaculture Alliance (GAA) - an industry association and the sponsor of the BAP program - released a booklet of best management practices for shrimp farmers. The booklet was assembled almost exclusively by industry representatives with some limited academic involvement. ${ }^{7}$ NGOs like WWF immediately pushed-back against the GAA initiative, arguing that it was irresponsible to create a list of 'best practices' for sustainable aquaculture without first consulting stakeholders from ENGOs, academia and public regulatory bodies. However, as one former WWF employee notes: 'at the time, GAA wasn't interested in hearing what the problems were'. ${ }^{8}$ GAA was essentially a closed operation with little need or appetite for broader stakeholder engagement.

The degree to which shrimp farmers would follow these best practice guidelines was unclear. BAP did not initially offer an option for third-party certification. While GAA considered developing an independently verified eco-label as early as 2003, this option was deemed 'too costly, complex and prone to liability' (Global Aquaculture Alliance, 2003). When the best practice guidelines were eventually converted into a series of species-specific standards, GAA created a new organization [the Aquaculture Certification Council (ACC)] to certify farms against their standards. However, by the GAA's own admission, the ACC did not have the necessary independence to act as a certification body. ${ }^{9}$ There was too much of a financial connection between the ACC and GAA to mitigate against potential conflicts of interest. Every producer approved by the ACC essentially meant more certification revenue for GAA. Thus, in the early years of the BAP program, the credibility, impartiality and representativeness of its standards were questionable. BAP was essentially an industry-only operation with a financial interest in keeping the stringency of its standards low in order to garner revenues from certification and logo licensing.

However, this changed as BAP sought to expand market uptake and confronted a growing amount of pushback from major seafood buyers. When BAP first learned that Walmart and several other large retailers were interested in sourcing certified sustainable farmed seafood, it saw an opportunity to seize control of the market and gain a modicum of financial independence. As one employee commented: 'we wanted to be one of the leading certification bodies ... and we wanted to set up a viable business model such that the revenues from running the program would cover the cost of staff and so that we wouldn't have to depend on the money from foundations necessarily'. ${ }^{10}$ However, BAP also knew that it might struggle to gain retail buy-in as long as it remained a closed operation with a financial stake in gaining certification revenues through a quasi-independent certification body (the ACC).

For its part, Walmart was concerned about choosing the right third-party standard. As early as 2004, Conservation International (CI) - working at Walmart's behest - began vetting potential certification partners to ensure that they possessed 
the requisite impartiality for CI to continue working with Walmart on farmed seafood (Global Aquaculture Alliance, 2006). At the time, BAP did not. Seeing an immediate threat to its prospects to gain access to Walmart's massive network of seafood suppliers, BAP was forced to reevaluate the financial connection between its standard setting activities and its conformance assessment body. As one GAA employee observes: 'we soon realized we were barking up the wrong tree. So, we redesigned our program to be compatible with ISO 65 where you have this guaranteed separation of the standard setter and the inspection body'.11

The move to decouple auditing from standard setting activity was the first consequence of Walmart's influence, but the changes grew and continued from there. Walmart, in tandem with its NGO partners, pushed the organization to become more representative of diverse stakeholder groups. As a GAA employee recalls:

Walmart went to Conservation International and said 'there's a bunch of certifications out there, which ones do you think we should go with?' And Conservation International said to us 'we think you would be a good fit, but you need to reorganize yourself ... You have a lot of technical knowledge and you have a lot of industry backing, but you don't have any proper engagement from NGOs. If you can rearrange your governance structures and make your standards development and certification process fully independent, then you are going to get some support from the NGO community. So on that basis we said: 'OK'. ${ }^{12}$

BAP began to review and overhaul its standard development procedures in late 2005 (Global Aquaculture Alliance, 2005). The decision to improve practices related to stakeholder engagement was a direct result of BAP's desire to gain access to Walmart's enormous network of suppliers. Knowing that Walmart and other large retailers are acutely vulnerable to NGO scrutiny and that multistakeholder governance was a prerequisite to winning their business, BAP moved to make its standard setting procedures more open to NGO involvement. Hence a second consequence of Walmart's influence was a growing concern for diverse stakeholder representation within the third-party standard setter.

BAP went from developing its standards in-house and with limited external consultation to conducting extensive stakeholder engagement and public review on each of its standards. It shifted from using an auditing system with questionable impartiality to allowing certification only after an independent third-party audit had been conducted. It also changed from a governance structure composed principally of industry stakeholders to a balanced committee-based governance model where each committee comprises four members of academic/regulatory bodies, four members of environmental/social NGOs and four members of industry. A majority vote is required to approve/change a standard and at least two members from each group must consent before a standard is passed. ${ }^{13}$ In addition to procedural improvements, conversations between Walmart and CI also resulted in 'more defined protection for wetland areas and greater consideration of feed conversion and fishmeal use' (Global Aquaculture Alliance, 2006). Thus, in this case, the power and influence of a lead firm may have actually strengthened impartiality, inclusiveness and stringency in a TSS.

\section{Explaining the Walmart-BAP interaction}

The Walmart-BAP case brings a number of questions to the fore: first, why would a lead firm take an interest in the governance and standard setting procedures of a 
nominally independent third-party standard setter? Second, why is the consequence of this interaction increased rigor and impartiality in standard setting and enforcement? Third, what is the source of Walmart's power in this interaction and how is it operationalized? Several literatures provide partial answers to these questions, however each only provides one piece of the broader puzzle.

Marxian accounts of multinational corporations have long anticipated the power of lead firms over political institutions and would view lead firm influence over TSS as an extension of this broader pattern. Hymer (1979), for example, previsions the emergence of TSS as an outcome of the internationalization of capital and labor and the emergence of supranational institutions that erode the traditional authority of nation-states. Viewed through this lens, TSS is an instrument of international capital to create a unified code on the rights of private property. A similar logic underlies Selwyn's (2015) argument that lead firms use various forms of GVC governance to displace the impacts of creative destruction - the process through which an economic structure revolutionizes itself from within by destroying the old one, incessantly creating new structures (Schumpeter, 1976) - onto upstream suppliers. Certified products represent a form of innovation that simultaneously increases the value of certified goods while reducing the value of conventional products, thus it could be construed as a manifestation of creative destruction. Yet, lead firms are insulated from the redistribution of value that accompanies creative destruction because they displace the costs of certification (i.e. paying for audits, changing production practices) onto suppliers while reaping many of the rewards of higher markups on certified goods. This dynamic, then, may partially explain why Walmart engaged with third-party TSS and pushed for changes that resulted in a more stringent and costly standard. It did so because it is insulated, to some extent, from how changes to the standard will increase input costs (Bloomfield, 2017a, p. 142). One limitation of this line of reasoning is that it offers few insights into the sources of Walmart's power or how and when they may vary. For example, would Walmart behave the same way to a third-party standard setter in another sector? Under Marxian accounts, power tends to flow primarily outward from multinational corporations, regardless of sector or issue specific-criteria.

The GPN literature provides a more nuanced account of lead firm power. GPN scholars have been critical of the concept of a GVC because of its presumed linearity, inattention to issues of the reproduction of labor power, and its dismissal of the autonomy of firms within a production system (Henderson et al., 2002). The concept of a network allows power to be theorized in a 'multidirectional and nondeterministic fashion' that could therefore extend to peripheral actors in a GPN, including NGOs and third-party standard setters (Bloomfield, 2017b; Henderson et al., 2002, p. 445). GPNs 'resemble contested organizational fields in which actors struggle over the construction of economic relationships, governance structures, institutional rules and norms and discursive frames' (Levy, 2008, p. 944). Power, in this case, is divided between Walmart, BAP, Conservation International and other concerned stakeholders. Walmart's power over BAP is constrained by countervailing forces, thus explaining why it does not simply push for a lowest common denominator standard. The GPN conception of power as both multidirectional and multi-faceted leaves open the possibility that lead firm and TSS power dynamics will vary according to the nature of the GPN, but does not offer a framework for anticipating where and when this may occur. 
The business power in global governance literature directly addresses the question of how lead firm power is operationalized. Doris Fuchs and her collaborators identify three distinct categories of business power: instrumental, structural and discursive (Fuchs, 2005, 2007; Fuchs et al., 2009; Fuchs \& Lederer, 2007). Instrumental power, in this context, can be thought of as the direct influence of lead firms on third-party standard setters expressed through material incentives or coercion. For example, by virtue of their superior resources, lead firms are better equipped to shape the development or revision of TSS by devoting staff to participate in multistakeholder standard negotiations (Bennett, 2017; Fuchs et al., 2009). This power eludes most ENGOs or smallholder producers. Structural power, in this context, can be thought of as the extent to which the centrality of lead firms to the global economy predetermines the behavioral options available to standard setters. No TSS can, for example, raise production costs to the extent that it may jeopardize the decision of lead firms to sell a particular line of product and thereby affect a key component of a national economy. Lastly, lead firms have discursive power insofar as they disseminate norms and ideas that shape the nature and form of the institutions that govern them, including third-party standard setters. Lead firms operationalize this power by representing themselves as the best-positioned actors to advocate for the social and environmental values of consumers, grounding their arguments in notions of efficiency and effectiveness. Hence, the source of Walmart's power is its commanding position within the global economy. It operationalizes this power through multiple avenues, both passively (structural) and actively (instrumental and discursive). As to what conditions might accord lead firms more or less power, the business power in global governance literature would consider objective qualities like the size of the firm and its importance to national economies. These are important variables, but they do not include the power that flows explicitly from the position of lead firms within certain types of GVCs.

Here, the GVC literature provides further analytic leverage. Gereffi et al. (2005) identify five types of value chain governance that occupy a spectrum between purely market-based governance and vertically-integrated hierarchical relationships. The nature of governance within a particular GVC is contingent on three binary variables: the complexity of transactions, codifiability of information and capability of suppliers. The authors note that when the ability to codify and the complexity of product specifications are both high but supplier capabilities are low (as they are in agrifood chains governed by TSS) then value chain governance will tend toward a 'captive' type wherein power is concentrated in a lead firm. Hence, the GVC literature helps explain variation in lead firm power over suppliers according to the characteristics of particular value chains but says little about how this power is exercised and to what ends. A GVC analysis could convincingly explain why Walmart holds power over its suppliers in the aquaculture GVC, but would stop short of explaining why it would use that power to push for more stringent TSS or how that power might extend beyond the value chain to affect third-party standard setters. There is therefore a critical step missing in the extant GVC literature explaining what a captive value chain implies for the power of both Walmart and BAP.

In sum, each of these literatures provides a piece of the puzzle explaining lead firm power over third-party TSS, but none explains the Walmart-BAP puzzle entirely. Doing so requires a more nuanced understanding of how a lead firm's position within a particular GVC serves as a basis of power that is independent of 
qualities like size and material resources. The conception of gatekeeper power developed in the following section describes how positionality defines the relationship between lead firms and third-party TSS. An understanding of the relational quality of power, in turn, provides a basis for synthesizing insights from these literatures to build hypotheses about how different types of GVCs and different sectorspecific qualities might alternately increase or decrease the power of lead firms over third-party TSS.

\section{Lead firms as 'gatekeepers'}

The concept of a 'gatekeeper' provides a useful heuristic for understanding power in this transnational domain. A gatekeeper is someone or something within a network that holds the power to restrict or condition access to other actors within a network. Lead firms, by virtue of their position within agrifood GVCs, have the power to act as 'gatekeepers' to third-party standard setters seeking to access their broader networks of suppliers. By the same token, third-party standard setters sometimes act as gatekeepers to lead firms seeking to access the legitimacy and credibility of their ENGO partners. NGOs can be gatekeepers to networks of environmentally conscious consumers. Central to the idea of gatekeeping is a relational view of power; one that acknowledges that power is not inherently material, rather it emerges from, and depends on, relationships (Avant \& Westerwinter, 2016). This view of power 'flows from a relational ontology that sees actors as constituted by, rather than independent of, relations' (Avant \& Westerwinter, 2016, p. 6). Applying this approach to the preceding case study, one would observe that Walmart's power over BAP flows from its relationships with networks of suppliers. The nature of power within a given GVC/GPN is conditioned, to some extent, by the form and structure of relationships within that GVC/GPN. Conceptualizing power this way - as relational and different across production networks and commercial sectors - allows us to specify, with much greater precision the conditions under which we can expect more or less power to lie with lead firms, third-party standard setters, or other actors within a production network.

Gatekeeping, as a concept, has previously been employed in the literatures on corporate governance, networks in political science, and relational approaches to international relations. Within the corporate governance literature, a gatekeeper is someone in 'a monitoring role with some power to screen out or at least to grade or rate the persons or entities scrutinized by the "gatekeeper" (Coffee, 2006, p. 10). This could be an independent professional who withholds cooperation or consent to prevent wrongdoing. However, it could also be someone "who acts as a reputational intermediary to assure investors as to the quality of the "signal" sent by the corporate issuer' (Coffee, 2006, p. 2), for example auditors or credit rating agencies. Within this literature, the concept of reputational capital is central to the power of the gatekeeper alongside the idea that reputational capital can be awarded or withheld by actors outside the firm (Coffee, 2006, p. 3). While difficult to define, reputational capital involves the accumulation of trust over an extended period of time (Klewes \& Wreschniok, 2009). In this context, one can imagine third-party standard setters using their reputational capital to condition the response of ENGOs towards particular firms or industries. 
Gatekeepers also feature prominently in the literature on networks in political science and in relational approaches to international relations. Here again, the power of gatekeepers is derived from their position within a particular network and ability to restrict, condition or filter access to other actors within that network. In the field of human rights, for example, Clifford Bob defines gatekeepers as 'entities at the core of the human rights movement, whose support for a claim can boost it substantially' (Bob, 2011, p. 6). The gatekeepers in this case are human rights NGOs with credibility on a particular issue and strong, central ties to other important actors within a network (Carpenter, 2016, p. 46). Their gatekeeper power is defined by their 'connectedness' (the number of organizations who establish or attempt to establish links with the NGO) and by their 'between-ness' (the degree to which the NGO possesses exclusive ties to otherwise marginalized or weakly connected nodes) (Carpenter, 2016, p. 46). Both characteristics are relevant to lead firms and TSS interactions. Lead firms hold gatekeeper power through the number of connections they hold to suppliers and other lead firms, but also through the exclusivity of their connection to particular suppliers within a network. The value of any one lead firm's gatekeeper power is therefore diminished if other firms have strong connections to a group of suppliers.

To further unpack the mechanisms through which gatekeeper power operates between lead firms and third-party standard setters, one first requires an understanding of the different priorities and accountabilities faced by third-party standard setters. Standard setters must carefully balance demand for credibility, stringency, legitimacy and effectiveness against a need for broad market uptake. On one hand, the core business of a third-party standard setter depends on independence and credibility. These attributes are primarily demonstrated by creating TSS that modify business behavior in meaningful ways. Many TSS grew directly out of ENGO efforts to hold corporations accountable. The World Wildlife Fund for Nature (WWF), for example, played a central role in founding the Forest Stewardship Council (FSC) and Marine Stewardship Council (MSC) to advance its work in global forests and fisheries, respectively. Hence, third-party standard setters can be viewed as policy instruments through which the WWF and similar NGOs advance their particular social or environmental agendas.

TSS that were not founded or funded by existing NGOs still have to demonstrate their independence and social/environmental credibility. A third-party standard-setter essentially serves as a trust-broker between producers and consumers who are spatially distant. The value proposition of TSS lie in their ability to affirm that a product or service has been produced in a way that is not detrimental to the environment or harmful to workers, even if buyers of the product have no way of ascertaining this information themselves. Hence, trust is at the core of a third-party standard setter's business model. Often, consumer and activist perceptions of trustworthiness are derived, in part, from a third-party standard setter's connection to credible NGOs, academic institutions or regulatory bodies. These stakeholders form a vital part of the legitimating community for TSS and can therefore act as gatekeepers to other stakeholders, including markets of green consumers (Bernstein, 2011). Retaining impartiality and credibility is of the utmost importance to the value proposition of a third-party standard setter, and therefore, so too is maintaining strong connections to stakeholders that provide legitimating functions. 
On the other hand, TSS must also be widely used by industry and recognized by consumers in order to have an impact. After all, a sustainability standard with no users and no consumer awareness can neither modify production or consumption in a way that benefits people or the environment. Thus, if the ultimate goal of most TSS is to transform markets, then they are most likely to do so when they are adopted by a sufficiently large percentage of a target market and across a broad geographic area (Kalfagianni \& Pattberg, 2013). Not only is market uptake crucial for achieving governance outcomes, it is also essential to the survival of third-party standard setters. Many such organizations depend on revenue from certification and logo licensing to finance their core business operations. For example, the MSC derived $72 \%$ of its total income in F2013/14 from royalties accrued through logo licensing (MSC, 2014). Absent broad usage, third-party standard setters are dependent on sporadic funding from foundations, grants, and industry-sources, all of which become increasingly tenuous if a standard is perceived as being largely irrelevant within its target sector.

Here then, is where lead firms - particularly retailers and supermarkets in captive buyer-driven agrifood GVCs - play a crucial role as gatekeepers to broader market uptake. In order to ensure that their standards are used by a broad market segment, third-party standard setters often have to work their way into the sustainable procurement policies of major agrifood buyers. The rationale behind this strategy lies in the economic leverage that lead firms hold in GVCs (Gereffi \& Korzeniewicz, 1994). As Mayer and Gereffi (2010, p. 8) note: 'firms with large market shares, whether marketers, retailers, or producers, usually have the option to source from many smaller suppliers, each of which may have few options other than doing business with the lead firm'. Third-party standard setters recognize the commanding position of lead firms over their suppliers and target these firms in the hopes that they will push demand for their standards up and across their entire supplier network (Bartley \& Child, 2014). Large retailers and supermarkets thereby hold the key to obtaining an 'an uptake boost' (Kalfagianni \& Fuchs, 2015) and escaping from the proverbial 'green ghetto' (Dauvergne \& Lister, 2013, p. 147).

The central role of lead firms in increasing uptake of TSS is no secret. Indeed, strategies for market transformation focused on targeting retailers and supermarkets are explicitly diagrammed in the WWF's communication materials around its certification and labeling efforts (WWF, 2012). Lead firms are conceptualized as the stem of a champagne glass, providing a crucial bridge between suppliers (the base of the glass) and consumers (the bowl of the glass). By targeting a small number of lead firms, third-party standard setters can change the production patterns of millions of suppliers and the consumption habits of billions of consumers. Bonsucro, a third-party standard-setter for sustainable sugarcane, provides an example of this strategy. In lieu of convincing millions of individual sugarcane farmers to use its standard, or billions of consumers to purchase products containing certified sugarcane, Bonsucro targets lead firms like Coca-Cola to use its standard. A decision by Coke to source exclusively Bonsucro certified sugarcane, in turn, helps Bonsucro secure its long-term survival and fundamentally transform the sugarcane value chain. ${ }^{14}$

Of course, the reverse dynamic is equally possible. An inability of third-party standard setters to gain procurement commitments from lead firms can jeopardize the long-term viability of TSS. This dynamic has already been documented in 
several sectors. In 2014, WWF released a report critiquing European retailers for failing to support the Roundtable on Responsible Soy (RTRS). The report notes that the indifference of retailers: 'leaves producers with little incentive to certify their soy as responsible and risks the integrity of some of the world's most valuable ecosystems, like the Amazon, Cerrado and Chaco' (WWF, 2014, p. 3). Without retail support, two major Brazilian soya bean producer associations, Aprosoja and ABIOVE, have withdrawn from and actively campaigned against RTRS over objections to the stringency and costs associated with RTRS and lack of corresponding market benefits (Schleifer, 2017). Similar dynamics can be observed in the apparel sector, where the ability to get suppliers to participate in the International Labor Organization-sponsored Better Work program 'became contingent on their ability to get buyers to participate' (Bair, 2017, p. 181).

The importance of the assent of lead firms to the continued survival and relevance of agrifood TSS creates a complicated power dynamic. Lead firms act as gatekeepers to their broader networks of suppliers, thereby affording them power over third-party standard setters that is at once instrumental, structural, and discursive. Instrumental inasmuch as lead firms often overtly use their commanding position within GVCs to cajole, coerce and incentivize nominally independent standard setters to create standards that align with their interests. Structural insofar as the power of lead firms flows from the broader condition of market consolidation that exists across many agrifood GVCs. Discursive inasmuch as decisions to withhold support from particular standards are often announced in full view of the media and waged through appeals to consumers under the guise of protecting their interests. Importantly, all three dimensions of gatekeeper power depend on relations within a GVC and sector-specific conditions. Thus, the power of lead firms over other actors in a production network is both dynamic and contingent.

Gatekeeper power can also flow in the opposite direction. Third-party standard setters can act as gatekeepers to networks of green consumers and supportive ENGOs, thereby constraining the access of lead firms to vital sources of revenue and reputational capital. The relative power of third-party standard setters over lead firms is also contingent on sector-specific dynamics, like the degree of public scrutiny on a particular industry. In scrutinized sectors, overt efforts to compromise the credibility of TSS risks incurring the wrath of an increasingly watchful and strategic cohort of ENGOs, social media users, and journalists. As WWF's market transformation strategy illustrates, these stakeholders are often all too aware of the leverage points that exist within GVCs. Hence, while occupying the role of lead firm in agrifood GVCs at once confers enormous power on retailers and supermarkets, this power is also constrained by the degree of scrutiny directed at lead firms in a fragmented system of global governance where civil society pressure is, to some degree, pivoting from governments to private businesses. Both third-party standard setters and NGOs benefit from this condition of scrutiny and leverage their exclusive networks to exert countervailing gatekeeper power over lead firms.

A relational understanding of lead firm power helps explain why Walmart made the counterintuitive decision to push BAP towards increased procedural and substantive stringency. On one hand, Walmart held tremendous gatekeeper power over BAP by virtue of its position as a lead firm within a captive GVC. This position afforded Walmart connectedness and between-ness in relation to its diffuse network of suppliers, thereby increasing its power within the production network 
in relational terms (Carpenter, 2016). BAP, while nominally independent, had good reasons to listen to Walmart and implement the changes it suggested. On the other hand, aquaculture is a highly scrutinized sector where the stringency and impartiality of TSS are likely to be closely scrutinized. Conservation International, acting as a gatekeeper to networks of green consumers and other ENGOs, held considerable countervailing power in this case to convince Walmart to use its power in service of a different end. The outcome in this case was a lead firm pushing for a stronger more impartial third-party standard. However, it is important to recognize that this outcome was contingent on certain GVC and sector-specific dynamics. Had this been a different sector or GVC, BAP may have had little cause to listen to Walmart or Walmart may have sought to reduce, not improve, the stringency of BAP's standard setting procedures.

\section{When will gatekeeper power be exercised?}

If the power of lead firms and other actors within a production network is contingent on the configuration of that network, then it may be possible to ascertain which governance configurations or sectoral conditions will tilt the balance of power one way or the other. Drawing on deductive reasoning, insights from past scholarship, and inductive observation from the preceding Walmart-BAP case, this section identifies a few sector and GVC-specific variables that may sway the balance of gatekeeper power towards lead firms or third-party standard setters. The list summarized in Table 1 provides a starting point for theorizing power relations between lead firms and third-party standard setters. It is by no means exhaustive, but it does aim to present some of the more influential categories of variables.

First, in GVCs that are captive, the gatekeeper power of lead firms may be higher since relationships to suppliers are more direct, exclusive, and hierarchical. Conversely, lead firm gatekeeper power may be moderated in GVCs that approximate market governance, where power is more evenly distributed between lead firms and their suppliers (Gereffi et al., 2005). The distinction flows from the ability of a lead firm in either condition to demand compliance with particular TSS across its value chain. In sectors like footwear and electronics, Asian-based suppliers have 'upgraded' by developing core competencies in manufacturing and product design, and thus, have developed a more collaborative 'partnership' with global buyers (Locke, 2013, p. 32). Under these conditions, a lead firm's decision to use TSS is more likely to meet with resistance from powerful suppliers, thereby constraining the amount of gatekeeper power the lead firm can exert over third-party standard setters.

Second, where purchasing power or economic leverage are equally divided amongst many lead firms within a single GVC, the gatekeeper power of any one of

Table 1. Potential conditions affecting the gatekeeper power of lead firms.

\begin{tabular}{lll}
\hline Variable & Value of variable & $\begin{array}{l}\text { Gatekeeper power } \\
\text { of lead firm }\end{array}$ \\
\hline 1. GVC governance & GVC is captive or strongly hierarchical & High \\
2. Number/power of lead firms in a GVC & Multiple powerful lead firms & Low \\
3. Number/relevance of TSS & Multiple relevant TSS within a sector & High \\
4. Number/power of suppliers in a GVC & Multiple powerful suppliers & High \\
5. Sector scrutiny & High public scrutiny & Low \\
\hline
\end{tabular}


those firms may be lower. A plurality of lead firms allows TSS multiple access points to supplier networks. Where decision-making power over TSS is diffused and less traceable (e.g. the GVC for coffee), lead firms will have less direct influence over suppliers, and consequently be less powerful as gatekeepers to third-party standard setters. By contrast, where decision-making power is concentrated and traceable (as in the garment industry), lead firms will exert more gatekeeper power (MacDonald, 2014).

Third, in sectors populated by multiple competing TSS, lead firms may hold more gatekeeper power. Fragmentation amongst TSS opens the possibility that lead firms may 'forum shop' for the least costly standards (Raustiala \& Victor, 2004). Under these conditions, the gatekeeper power of third-party standard setters may be moderated as they no longer provide exclusive access to specific markets or actors who provide reputational capital (i.e. green consumers or ENGOs). If a lead firm holds exclusive access to its pool of suppliers, it may be able to leverage this gatekeeper power to lower barriers to certification and trigger a regulatory race to the bottom (Abbott \& Snidal, 2010, p. 324; Fransen, 2011; Gulbrandsen, 2005). Gatekeeper power is augmented under these conditions by the ability of lead firms to use either exit (switching to other TSS) or voice (reworking TSS to suit their own needs) (Hirschman, 1970).

Fourth, when production is highly fragmented between suppliers or when economic power is evenly dispersed across them, a lead firm may be more likely to hold gatekeeper power. The logic being that third-party standard setters will be less inclined and capable to approach multiple independent producers and will depend upon lead firms as nodes in a production network to exert pressure on their suppliers to get certified to a particular TSS. The gatekeeper power of lead firms in this scenario flows from their centrality and connectedness in diffuse production networks. As in the Walmart case, third-party standard setters can either convince millions of smaller aquaculture producers to use their standards, or simply target Walmart and watch the decision ripple up the value chain. In this scenario and others like it, Walmart holds tremendous relational power over TSS. Conversely, in sectors where production is highly concentrated amongst a few large firms (e.g. palm oil), TSS have the option of working directly with a handful of large-scale producers, thereby reducing the relational power of lead firms (Lowder, Skoet, \& Raney, 2016).

Fifth and finally, lead firm gatekeeper power may be lower when they work in a sector that is the focus of comparatively high levels of public scrutiny or social pressure (Mayer \& Gereffi, 2010). Retailers who buy consumer staples like bananas or farmed seafood are both highly visible and vulnerable to social pressure through high profile NGO campaigns on issues like agrochemical pollution or slavery in the aquaculture industry. Thus, while buyers are heavily consolidated in these sectors and production is fragmented, third-party standard setters may hold additional power by virtue of their exclusive access to actors with reputational capital. By contrast, commodities like soy are often purchased by a range of less scrutinized companies that use it for feedstock, thereby eschewing scrutiny and reducing the gatekeeper power of NGOs and third-party standard setters. This could help explain why major buyers have pushed back vocally on prominent TSS for soy (Schleifer, 2017). 
While these conditions have yet to undergo rigorous empirical testing, they may provide a starting point for explaining variation in power dynamics between lead firms and third-party standard setters. Assessing the analytic value of these variables will require theorizing interaction effects to ascertain which constellation of values produces the most gatekeeper power for lead firms or third-party standard setters. It will also require a robust technique for measuring cause-effect relationships and tracing causal mechanisms. Network analysis may be useful for measuring the value of gatekeeper power by examining the relative connectivity of actors within a network (Ward, Stovel, \& Sacks, 2011). Process tracing would then play a vital role in determining whether those actors who are better connected exert more influence over TSS (Checkel \& Bennett, 2015). One could do so by examining detailed public records of stakeholder input into the creation and revision of TSS. Many third-party standard setters, particularly those that adhere to the ISEAL Standard Setting Code, track both the comments they receive and their responses to those comments (ISEAL Alliance, 2014). By tracing the timing and sequencing of particular changes to TSS in response to well-connected actors in a network, one may be able to ascertain the presence or absence of instrumental gatekeeper power. Web-based archival research can provide further insights into the timing and sequencing of changes to the governance of third-party standard setters relative to their relationship with lead firms. Lastly, key informant interviews are a vital tool for determining the impact of structural and discursive gatekeeper power on TSS.

\section{Conclusion}

Retailers and supermarkets, as lead firms in buyer-driven GVCs, act as 'gatekeepers' to third-party standard setters seeking to govern global agrifood production. The survival of third-party standards and their ability to achieve broader global governance objectives often depends on market uptake. Simply put, they need suppliers to abide by their standards, pay for compliance audits, and license their logos in order to stay in business. However, the costs of doing so are often more than producers are willing to pay absent some external motivation. In GVCs with a high degree of fragmentation on the production side and strong consolidation on the buyer side, that motivation often comes in the form of requests for certified sustainable products from lead firms. Thus, for third-party standard setters: 'securing the participation of buyers is something of a necessary condition for incentivizing suppliers to join the program' (Bair, 2017, p. 176). The substantive effect of this power dynamic is that lead firms often hold considerable power over nominally independent TSS. This power is constrained in sectors where there are fewer relevant transnational standards and high public scrutiny. Under such conditions, third-party standard setters may exert countervailing gatekeeper power by virtue of their exclusive access to networks of green consumers and supportive NGOs.

By theorizing power as relational and different across production networks and commercial sectors, gatekeeper power offers a framework for explaining outcomes not anticipated by past accounts of business power over regulatory bodies. Whereas much of the existing literature suggests that businesses use their power to weaken or capture regulatory institutions (Fuchs \& Kalfagianni, 2010; Hymer, 1979), the Walmart-BAP case suggests that power can be used for other ends as 
well. Gatekeeper power builds on the GPN literature's conception of production networks as contested organizational fields encompassing diverse actors in which power is relational, multifaceted, and multidirectional (Henderson et al., 2002). This conception of power, when combined with insights from the literatures on GVCs and transnational governance, can help explain why certain GVC governance configurations or sector-specific conditions may accord lead firms more or less power or cause them to use their power in counterintuitive ways. Gatekeeper power complements Fuchs' $(2005,2007)$ tripartite conception of business power as instrumental, structural, and discursive by showing how these mechanisms equally apply to emergent forms of transnational governance. However, it is unique in rooting a lead firm's power in its position within a GVC, thereby suggesting that business power is more dynamic and contingent than often theorized.

This study shows that much could be gained through a closer engagement between scholars of international political economy and transnational governance. For scholars of transnational governance, a more fine-grained analysis of how the complexity of transactions, the codifiability of information, and the capability of suppliers within a given GVC alters the interaction between lead firms and thirdparty standard setters could yield important insights into when TSS are most likely to achieve desirable governance outcomes. Put differently, the taxonomies of GVCs developed by international political economists could become important independent variables for explaining the form and efficacy of transnational governance in different commercial sectors. For scholars of international political economy, a closer examination of the symbiotic relationship between transnational standard setters and lead firms could yield novel insights into the conditions that enable firms to upgrade or downgrade. In other words, if third-party standard setters condition the power dynamics within GVCs, then much can be gained by studying how these institutions are molded and shaped by the very GVCs they seek to govern.

Gatekeeper power offers a novel perspective on how changes to the global economy affect the capacity of regulatory institutions to achieve global governance outcomes, like ensuring workers' rights or protecting the environment. Some scholars have warned of the perils of concentrating power into an ever smaller set of hands, thereby creating cadres of influential gatekeepers (Fuchs et al., 2009). Given the dependence of third-party standard setters on lead firm support across many sectors, one may be reasonably concerned about the substance of TSS. Moreover, if the ultimate goal of suppliers is to continue to secure stable contracts from lead firms - and not to improve production sustainability - then legitimate questions may be raised about whether following standards coercively imposed by lead firms will contribute to durable behavioral change at the site of production. As an emerging body of research shows, there is a marked difference between following the letter of the law and actually internalizing behavioral change (Starobin, 2017). Viewed pessimistically, lead firms are simply protecting their brands while encouraging third-party standard setters and suppliers to do just enough to guard against reputational threats.

On the other hand, there are also some discernible advantages to industry consolidation. Namely, consolidation provides enormous leverage points for activists and international organizations (IOs). If a handful of firms control the production, distribution, and transportation of an entire commodity, then activist or IO resources can be concentrated to alter the behavior of those firms. This strategy has 
already been adopted by NGOs like the WWF through market transformation initiatives that deliberately target a handful of lead firms in sectors where commodity production contributes to important environmental issues (WWF, 2012). It could further be adopted by IOs as part of the ongoing turn towards orchestration and mobilizing private actors to achieve public regulatory goals (Abbott, Genschel, Snidal, \& Zangl, 2015). In cases where concerted social pressure can nudge lead firms towards partnering with credible third-party TSS, the consolidation of purchasing power in the global economy offers new potential for using GVCs to achieve global governance outcomes.

\section{Notes}

1. This article mainly uses the shorthand 'GVC' to refer to the multinational sites of production that TSS seek to govern. It does so with the knowledge that there is an ongoing debate about whether 'global production network' (GPN) is a more appropriate conceptualization than GVC (Henderson, Dicken, Hess, Coe, \& Yeung, 2002). Following the example of other authors (Mayer \& Phillips, 2017), I use GVC here not to privilege one side of the debate over the other, but rather out of a concern for brevity and with the understanding that the differences between GVC and GPN approaches are arguably narrowing(Coe, 2012, p. 390). The rich contributions of the GPN literature feature prominently later in this article.

2. Lead firms are the businesses in GVCs that wield the most economic clout. They can be either buyers or sellers of goods, depending on whether a GVC is buyer or producer-driven (Gereffi \& Korzeniewicz, 1994).

3. I use 'downward pressure' here to refer to processes through which third-party standard setters become less independent or impartial and more susceptible to influence from the businesses they seek to govern. Downward pressure can also refer to making standard criteria easier to achieve, and therefore, less costly for industry. Common sense dictates that the former strongly influences the latter.

4. Retailers and supermarkets have relatively less power in GVCs for processed foods, including high-value bean crops like coffee or cocoa. In such cases, manufacturers often play the role of lead firms and have more direct power over producers (Lee, Gereffi, \& Beauvais, 2012).

5. The emergence of TSS is well documented elsewhere and does not require a full recounting here. Their origins have been documented using a diverse terminology, including: private governance (Auld 2014; Auld, Renckens, \& Cashore 2015; Bernstein, 2014; Falkner, 2003; Fransen, 2011; Fransen \& Conzelmann, 2015), private regulation (Bartley, 2003, 2007; Büthe, 2010), non-state market-driven (NSMD) governance (Bernstein, 2011; Bernstein \& Cashore, 2007; Cashore, 2002; Cashore, Newsom, \& Auld, 2004), experimental governance (Hoffmann, 2011), non-state certification (Auld \& Gulbrandsen, 2010; Auld, Gulbrandsen, \& McDermott, 2008; Gulbrandsen, 2014), standard-setting (Bartley, Koos, Samel, Setrini, \& Summers, 2015; Büthe \& Mattli, 2011; Mattli \& Büthe, 2005), rule-setting transnational governance (Andonova, Betsill, \& Bulkeley, 2009), transnational business-governance (Eberlein, Abbott, Black, Meidinger, \& Wood, 2014), transnational new governance (Abbott, Genschel, Snidal, \& Zangl, 2015; Abbott \& Snidal, 2010), voluntary environmental programs (Potoski \& Prakash, 2005, 2010), and voluntary sustainability standards (Bennett, 2017). I use TSS here to denote cross-national governing authority, broad sustainability focus, and a diversity of actors involved, including private and public organizations.

6. Interviews were conducted with the understanding that organizational affiliation would be included, but names would be omitted. This decision reflects a balance between encouraging candor in interviewees while still acknowledging background and role. 
7. Interview, Global Aquaculture Alliance Employee, 8 December 2014.

8. Interview, Aquaculture Dialogues Convener, 8 December 2014.

9. Interview, Global Aquaculture Alliance Employee, 8 December 2014.

10. Interview, Global Aquaculture Alliance Employee, 8 December 2014.

11. Interview, Global Aquaculture Alliance Employee, 8 December 2014.

12. Interview, Global Aquaculture Alliance Employee, 8 December 2014.

13. Interview, Global Aquaculture Alliance Employee, 8 December 2014.

14. Coca-Cola has committed to sourcing $100 \%$ sustainable sugarcane by 2020 , although its progress towards this goal remains unclear (Smedley, 2014).

\section{Disclosure statement}

No potential conflict of interest was reported by the author.

\section{ORCID}

Hamish van der Ven (D) http://orcid.org/0000-0002-9223-9080

\section{References}

Abbott, K. W., Genschel, P., Snidal, D., \& Zangl, B. (Eds.). (2015). International organizations as orchestrators. Cambridge: Cambridge University Press.

Abbott, K. W., \& Snidal, D. (2010). International regulation without international government: Improving IO performance through orchestration. Review of International Organizations, 5(3), 315-344.

Andonova, L. B., Betsill, M. M., \& Bulkeley, H. (2009). Transnational climate governance. Global Environmental Politics, 9(2), 52-73.

ASC. (2017). Certification update: November 2017. Retrieved from http://mailchi.mp/asc-aqua/ xr162vrjvq-1826217? $=9$ ebd51a70d

Auld, G. (2014). Constructing private governance: The rise and evolution of forest, coffee, and fisheries certification. New Haven, CT: Yale University Press.

Auld, G., \& Gulbrandsen, L. H. (2010). Transparency in nonstate certification: Consequences for accountability and legitimacy. Global Environmental Politics, 10(3), 97-119.

Auld, G., Gulbrandsen, L. H., \& McDermott, C. L. (2008). Certification schemes and the impacts on forests and forestry. Annual Review of Environment and Resources, 33(1), 187-211.

Auld, G., Renckens, S., \& Cashore, B. (2015). Transnational private governance between the logics of empowerment and control. Regulation \& Governance, 9(2), 108-124.

Avant, D. D., \& Westerwinter, O. (2016). The new power politics: Networks and transnational security governance. New York, NY: Oxford University Press.

Bair, J. (2017). Contextualising compliance: Hybrid governance in global value chains. New Political Economy, 22(2), 169-185.

BAP. (2017). Volume of seafood from BAP-certified processing plants. Retrieved from https://bapcertification.org/blog/wp-content/uploads/2017/01/BAP_Graph_Volume_BAP-Product_June_ 2017-01.png

Bartley, T. (2003). Certifying forests and factories: States, social movements, and the rise of private regulation in the apparel and forest products fields. Politics \& Society, 31(3), 433-464.

Bartley, T. (2007). Institutional emergence in an era of globalization: The rise of transnational private regulation of labor and environmental conditions. American Journal of Sociology, 113(2), 297-351.

Bartley, T., \& Child, C. (2011). Movements, markets and fields: The effects of anti-sweatshop campaigns on U.S. firms, 1993-2000. Social Forces, 90(2), 425-451.

Bartley, T., \& Child, C. (2014). Shaming the corporation: The social production of targets and the anti-sweatshop movement. American Sociological Review, 79(4), 653-679. 
Bartley, T., Koos, S., Samel, H., Setrini, G., \& Summers, N. (2015). Looking behind the label: Global industries and the conscientious consumer. Bloomington, IN: Indiana University Press.

Bennett, E. A. (2017). Who governs socially-oriented voluntary sustainability standards? Not the producers of certified products. World Development, 91, 53-69.

Bernstein, S. (2011). Legitimacy in intergovernmental and non-state global governance. Review of International Political Economy, 18(1), 17-51.

Bernstein, S. (2014). The publicness of private global environmental and social governance. In J. Best \& A. Gheciu (Eds.), The return of the public in global governance (pp. 120-148). Cambridge: Cambridge University Press.

Bernstein, S., \& Cashore, B. (2007). Can non-state global governance be legitimate? An analytical framework. Regulation \& Governance, 1(4), 347-371.

Bloomfield, M. J. (2017a). Dirty gold: How activism transformed the jewelry industry. Cambridge, MA: MIT Press.

Bloomfield, M. J. (2017b). Global production networks and activism: Can activists change mining practices by targeting brands? New Political Economy, 22(6), 727-742.

Bob, C. (2011). The international struggle for new human rights. Philadelphia, PA: University of Pennsylvania Press.

Burch, D., \& Lawrence, G. (2007). Supermarkets and agri-food supply chains: Transformations in the production and consumption of foods. Northampton, MA: Edward Elgar.

Büthe, T. (2010). Private regulation in the global economy: A (P)Review. Business and Politics, 12(03), 1-38.

Büthe, T., \& Mattli, W. (2011). The new global rulers: The privatization of regulation in the world economy. Princeton, NJ: Princeton University Press.

Carpenter, C. (2016). Network relations and human security norm development. In D. D. Avant \& O. Westerwinter (Eds.), The new power politics: Networks and transnational security governance (pp. 41-73). New York, NY: Oxford University Press.

Cashore, B. (2002). Legitimacy and the privatization of environmental governance: How non-state market-driven (NSMD) governance systems gain rule making authority. Governance, 15(4), 503-529.

Cashore, B., Newsom, D., \& Auld, G. (2004). Governing through markets: Forest certification and the emergence of non-state authority. New Haven, CT: Yale University Press.

Checkel, J. T., Bennett, A. (Eds.). (2015). Process tracing: From metaphor to analytic tool. New York, NY: Cambridge University Press.

Cheddar Berk, C. (2017). Amazon and whole foods control only a sliver of the grocery market-for now. Retrieved from https://www.cnbc.com/2017/06/16/amazon-whole-foods-control-onlysliver-of-the-grocery-market-for-now.html

Coe, N. M. (2012). Geographies of production II: A global production network A-Z. Progress in Human Geography, 36(3), 389-402.

Coffee, J. (2006). Gatekeepers: the professions and corporate governance. New York, NY: Oxford University Press.

Costco. (2017). Sustainable fisheries. Retrieved from https://www.costco.com/sustainability-fisheries.html

Darnall, N., Ji, H., \& Potoski, M. (2017). Institutional design of ecolabels: Sponsorship signals rule strength. Regulation \& Governance, 11(4), 438.

Dauvergne, P. (2016). Environmentalism of the rich. Cambridge, MA: MIT Press.

Dauvergne, P., \& LeBaron, G. (2014). Protest Inc.: The corporatization of activism. Cambridge, UK: Polity.

Dauvergne, P., \& Lister, J. (2013). Eco-business: A big-brand takeover of sustainability. Cambridge, MA: MIT Press.

Eberlein, B., Abbott, K. W., Black, J., Meidinger, E., \& Wood, S. (2014). Transnational business governance interactions: Conceptualization and framework for analysis. Regulation \& Governance, 8(1), 1-22.

Engle, C. R., Quagrainie, K. K., \& Dey, M. M. (2016). Seafood and aquaculture marketing handbook. Hoboken, NJ: John Wiley \& Sons.

Falkner, R. (2003). Private environmental governance and international relations: Exploring the links. Global Environmental Politics, 3(2), 72-87. 
FAO. (2014). The state of world fisheries and aquaculture. Rome: Food and Agriculture Organization of the United Nations.

FAO. (2016). The state of world fisheries and aquaculture. Rome: Food and Agriculture Organization of the United Nations.

Fold, N., \& Pritchard, B. (2005). Cross-continental agro-food chains: Structures, actors and dynamics in the global food system. London; New York: Taylor \& Francis.

Fransen, L. (2011). Why do private governance organizations not converge? A Political-Institutional analysis of transnational labor standards regulation. Governance, 24(2), 359-387.

Fransen, L., \& Conzelmann, T. (2015). Fragmented or cohesive transnational private regulation of sustainability standards? A comparative study. Regulation \& Governance, 9(3), 259-275.

Fuchs, D. (2005). Understanding business power in global governance. Baden-Baden: Nomos.

Fuchs, D. (2007). Business power in global governance. Boulder, CO: Lynne Rienner Publishers.

Fuchs, D., \& Kalfagianni, A. (2010). The causes and consequences of private food governance. Business and Politics, 12(03), 1-34.

Fuchs, D., Kalfagianni, A., \& Arentsen, M. (2009). Retail power, private standards, and sustainability in the global food system. In J. Clapp, S. K. Sell, D. Fuchs, M. Arentsen, A. Kalfagianni, \& S. Scott (Eds.), Corporate power in global agrifood governance (pp. 29-60). Cambridge, MA: MIT Press.

Fuchs, D., \& Lederer, M. M. (2007). The power of business. Business and Politics, 9(03), 1-17.

Gereffi, G. (2014). Global value chains in a post-Washington Consensus world. Review of International Political Economy, 21(1), 9-37.

Gereffi, G., \& Korzeniewicz, M. (1994). Commodity chains and global capitalism. Westport, CT: Greenwood Press.

Gereffi, G., Humphrey, J., \& Sturgeon, T. (2005). The governance of global value chains. Review of International Political Economy, 12(1), 78-104.

Global Aquaculture Alliance. (2003). Responsible aquaculture program. Retrieved from https://web. archive.org/web/20030712034707/http://gaalliance.org/resp.html

Global Aquaculture Alliance. (2005). GAA reviews BAP standards. Retrieved from https://web. archive.org/web/20050818110841/http://gaalliance.org/acti.html

Global Aquaculture Alliance. (2006). Wal-Mart, Darden specify BAP certification for shrimp suppliers. Retrieved from https://web.archive.org/web/20060209233125/http://www.gaalliance.org/acti. html

Gulbrandsen, L. H. (2005). Sustainable forestry in Sweden: The effect of competition among private certification schemes. Journal of Environment \& Development, 14(3), 338-355.

Gulbrandsen, L. H. (2014). Dynamic governance interactions: Evolutionary effects of state responses to Non-State certification programs. Regulation \& Governance, 8(1), 74-92.

Henderson, J., Dicken, P., Hess, M., Coe, N., \& Yeung, H. W.-C. (2002). Global production networks and the analysis of economic development. Review of International Political Economy, 9(3), 436-464.

Hirschman, A. O. (1970). Exit, voice, and loyalty: Responses to decline in firms, organizations, and states. Cambridge, MA: Harvard University Press.

Hoffmann, M. (2011). Climate governance at the crossroads: Experimenting with a global response after Kyoto. New York, NY: Oxford University Press.

Hymer, S. (1979). The multinational corporation: A radical approach. Cambridge, UK: Cambridge University Press.

ISEAL Alliance. (2014). ISEAL code of good practice for setting social and environmental standards-Draft version, 5, 3. Retrieved from http://www.isealalliance.org/sites/default/files/ ISEAL\%20Standard-Setting\%20Code\%20v5.31\%20FINAL\%20DRAFT\%20clean.pdf

Jaffee, D., \& Howard, P. H. (2010). Corporate cooptation of organic and fair trade standards. Agriculture and Human Values, 27(4), 387-399.

Kalfagianni, A., \& Fuchs, D. (2015). Private agri-food governance and the challenges for sustainability. In G. M. Robinson \& D. A. Carson (Eds.), Handbook on the globalisation of agriculture (pp. 274-290). Northampton, MA: Edward Elgar R.

Kalfagianni, A., \& Pattberg, P. (2013). Fishing in muddy waters: Exploring the conditions for effective governance of fisheries and aquaculture. Marine Policy, 38, 124-132.

Klewes, J., \& Wreschniok, R. (2009). Reputation capital: building and maintaining trust in the 21st century. Heidelberg, New York: Springer. 
Lee, J., Gereffi, G., \& Beauvais, J. (2012). Global value chains and agrifood standards: Challenges and possibilities for smallholders in developing countries. Proceedings of the National Academy of Sciences, 109(31), 12326-12331.

Levy, D. L. (2008). Political contestation in global production networks. Academy of Management Review, 33(4), 943-963.

Locke, R. M. (2013). The promise and limits of private power: Promoting labor standards in a global economy. Cambridge, UK: Cambridge University Press.

Lowder, S. K., Skoet, J., \& Raney, T. (2016). The number, size, and distribution of farms, smallholder farms, and family farms worldwide. World Development, 87, 16-29.

MacDonald, K. (2014). The politics of global supply chains. Cambridge, UK: Polity.

Marschke, M., \& Vandergeest, P. (2016). Slavery scandals: Unpacking labour challenges and policy responses within the off-shore fisheries sector. Marine Policy, 68, 39-46.

Mattli, W., \& Büthe, T. (2005). Accountability in accounting? The politics of private rule-making in the public interest. Governance, 18(3), 399-429.

Mayer, F. (2014). Leveraging private governance for public purpose: Business, civil society and the state in labour regulation. In A. Payne \& N. Phillips (Eds.), Handbook of the international political economy of governance (pp. 344-360). Cheltenham, UK: Edward Elgar.

Mayer, F., \& Gereffi, G. (2010). Regulation and economic globalization: Prospects and limits of private governance. Business and Politics, 12(3), 1-25.

Mayer, F. W., \& Phillips, N. (2017). Outsourcing governance: States and the politics of a 'global value chain world.' New Political Economy, 22(2), 134-152.

McDonalds. (2017). Our supply chain. Retrieved from http://corporate.mcdonalds.com/mcd/sustainability/sourcing/priority-products.html

Merino, G., Barange, M., Mullon, C., \& Rodwell, L. (2010). Impacts of global environmental change and aquaculture expansion on marine ecosystems. Global Environmental Change, 20(4), 586-596.

MSC. (2014). Trustee's report and accounts for the year ended 31st March 2014. Marine Stewardship Council. Retrieved from http://www.msc.org/documents/institutional/finance/mscaccounts-2013-2014/view

Mulvaney, K. (1998). A sea of troubles: in the international year of the ocean, are we reaching the limits? Environmental Magazine, 9(1), 28.

Potoski, M., \& Prakash, A. (2005). Green clubs and voluntary governance: ISO 14001 and firms' regulatory compliance. American Journal of Political Science, 49(2), 235-248.

Potoski, M., \& Prakash, A. (Eds.). (2010). Voluntary programs: A club theory perspective. Cambridge, MA: MIT Press.

Prakash, A. (2001). Why do firms adopt 'beyond-compliance' environmental policies? Business Strategy and the Environment, 10(5), 286-299.

Raustiala, K., \& Victor, D. G. (2004). The regime complex for plant genetic resources. International Organization, 58(2), 277-309.

Reardon, T., Barrett, C. B., Berdegué, J. A., \& Swinnen, J. F. M. (2009). Agrifood industry transformation and small farmers in developing countries. World Development, 37(11), 1717-1727.

Schleifer, P. (2017). Private regulation and global economic change: the drivers of sustainable agriculture in Brazil. Governance, 30(4), 687-703.

Schumpeter, J. A. (1976). Capitalism, socialism, and democracy. London: Allen and Unwin.

Selwyn, B. (2013). The global retail revolution, fruiticulture and economic development in northeast Brazil. Review of International Political Economy, 20(1), 153-179.

Selwyn, B. (2015). Commodity chains, creative destruction and global inequality: A class analysis. Journal of Economic Geography, 15(2), 253-274.

Smedley, T. (2014). Sustainable sugar: Coca-Cola and BP signed up but will it go mainstream? Guardian. Retrieved from https:/www.theguardian.com/sustainable-business/2014/sep/15/ sustainable-sugar-can-coca-cola-bp-shell-bonsucro

Starobin, S. (2017). Institutions, innovation, and grassroots change: Alternatives to transnational sustainability governance in the global south. Presented at the International Studies Association Annual Meeting, Baltimore, MD.

Tata. (2017). Sustainable sourcing. Retrieved from http://www.tataglobalbeverages.com/sustainability/ sustainable-sourcing

van der Ven, H. (2014). Socializing the C-suite: Why some big-box retailers are "greener" than others. Business and Politics, 16(1), 31-63. 
van der Ven, H. (2015). Correlates of rigorous and credible transnational governance: A crosssectoral analysis of best practice compliance in eco-labeling. Regulation \& Governance, 9(3), 276-293.

Waite, R., Phillips, M., \& Brummett, R. (2014). Sustainable fish farming: 5 strategies to get aquaculture growth right. Retrieved from http://www.wri.org/blog/2014/06/sustainable-fish-farming5-strategies-get-aquaculture-growth-right

Ward, M. D., Stovel, K., \& Sacks, A. (2011). Network analysis and political science. Annual Review of Political Science 14(1), 245-264.

WWF. (2012). Market Transformation Initiative Strategy. Retrieved from http://assets.panda.org/ downloads/how_the_wwf_markets_transformation_initiative_works.pdf

WWF. (2014). WWF Soy Report Card 2014. Retrieved from http://d2ouvy59p0dg6k.cloudfront. net/downloads/soyreportcard2014.pdf 